\title{
How do environmental impact assessments fail to prevent social conflict? Government technologies in a dam project in Colombia
}

\author{
Susana Carmona ${ }^{1}$ \\ Claudia Puerta Silva \\ Universidad de Los Andes, Colombia \\ Universidad de Antioquia, Colombia
}

\begin{abstract}
We analyze environmental impact assessment (EIA) for infrastructure development projects in Latin America through the case of the "El Cercado" dam on the Rancheria river in La Guajira Province of northern Colombia. We argue that social and environmental conflicts regarding development projects are not only the result of deficient EIA implementation but also of historically established power relations and deep-rooted beliefs concerning the economy and socio-spatial relations, of which EIAs are a constituting and enabling element. We focus on governmentality practices from an ethnographic political ecology perspective to trace how the EIA uses the concept of "areas of influence" as a standardized inclusion/exclusion technique, limited by its static nature and functioning as a legitimizing device for governmental interest to expand neoliberal economies in natural resource-strategic regions. Our analysis aims to understand how EIAs used for infrastructure development projects in Latin America have failed to prevent socio-environmental conflicts. At the same time, we question the notions of "space", "influence", and "affected population" behind EIA practices. We conclude that EIAs are a government technology of neoliberal environmental governance that has the potential to exclude the socio-spatial dynamics of local populations while depoliticizing the interests behind the project. With this article, we contribute to the ethnographic approach to governmentality in the context of infrastructure development projects in Latin America and to the understanding of the role of expert knowledge and technologies of government in neoliberal hydro-politics.
\end{abstract}

Keywords: Environmental Impact Assessment, dam, hydro-politics, government technologies, social conflict

\section{Résumé}

Dans cet article, nous analysons les Évaluation de l'impact sur l'environnement (EIE) des projets de développement des infrastructures en Amérique Latine, à travers le cas du barrage du fleuve Ranchería en Colombie. Nous soutenons que les conflits sociaux et environnementaux liés aux projets de développement ne sont pas seulement le résultat d'une mauvaise mise en œuvre des EIE, mais aussi de relations de pouvoir historiquement établies, et de croyances bien ancrées sur l'économie et les relations socio-spatiales, qui sont constitutives et permises par les EIE. Du point de vue de l'écologie politique et en mettant l'accent sur les pratiques de la gouvernementalité, nous adoptons une approche ethnographique du cas pour décrire comment l'EIE utilise la délimitation des "zones d'influence" comme une technique normalisée d'inclusion/exclusion, limitée par sa nature statique, et fonctionne comme un dispositif qui légitime l'intérêt gouvernemental à étendre

\footnotetext{
${ }^{1}$ Dr. Susana Carmona Castillo completed her Ph.D. at the Department of Anthropology at Universidad de Los Andes, Colombia and began her postdoctoral research at Maastricht University in the Netherlands in 2020. Email: s.carmona10 "at" uniandes.edu.co. Dr. Claudia Puerta Silva is an Associate Professor in the Department of Anthropology of the Universidad de Antioquia, Colombia and is affiliated with the Strategic Resources, Region and Socioenvironmental Dynamics research group in the Institute of Regional Studies. Email: claudia.puerta "at" udea.edu.co. This article reports outcomes of the project "Prior consultation and participation mechanisms: Spaces of participation of ethnic minorities and other communities in natural resources extraction, infrastructure and development projects," funded by Colciencias, Universidad de Antioquia and Universidad EAFIT. The authors are thankful to the people in La Guajira, and specially the people of Caracolí for their participation in this research, the editor Prof. Casey Walsh for his support in the editing process and the blind reviewers for their valuable comments. The authors would also like to thank the research group RERDSA and the Research Vicerectory of the Universidad de Antioquia for the funding provided for the initial proof-read of this article.
} 
les économies néolibérales dans des régions stratégiques pour leurs ressources naturelles. Notre analyse vise à comprendre comment les EIE des projets de développement des infrastructures en Amérique latine n'ont pas réussi à prévenir les conflits socio-environnementaux. En même temps, nous nous interrogeons sur les notions d"'espace", d'"influence" et de "population affectée" derrière les pratiques d'EIE. Nous concluons que les EIE sont une technologie de gouvernance propre à la gouvernance environnementale néolibérale qui a le potentiel d'exclure la dynamique socio-spatiale de la population locale tout en dépolitisant les intérêts derrière le projet. Avec cet article, nous contribuons à l'approche ethnographique du gouvernementalité dans le contexte des projets de développement des infrastructures en Amérique latine et à la compréhension du rôle des connaissances spécialisées et des technologies du gouvernement dans l'hydropolitique néolibérale.

Mots-clés: Évaluation de l'impact sur l'environnement, barrages, hydro-politique, technologies du gouvernement, conflits sociaux

\section{Resumen}

En este articulo analizamos los Estudios de Impacto Ambiental (EIA) para proyectos de desarrollo de infraestructura en América Latina, a través del caso de la represa del río Ranchería en Colombia. Argumentamos que los conflictos sociales y ambientales relacionados con proyectos de desarrollo no son sólo el resultado de una deficiente implementación de los EIA, sino de relaciones de poder establecidas históricamente y de creencias arraigadas sobre la economía y las relaciones socioespaciales, que con constitutivas y habilitadas por los EIA. Con una mirada desde la ecología política y enfocándonos en las prácticas de la gubernamentalidad, hacemos una aproximación etnográfica al caso para describir cómo el EIA utiliza la delimitación de "áreas de influencia" como una técnica de inclusión/exclusión estandarizada, limitada por su naturaleza estática y que funciona como un dispositivo legitimador del interés gubernamental para expandir las economías neoliberales en regiones estratégicas por sus recursos naturales. Nuestro análisis apunta a entender cómo los EIA para proyectos de desarrollo de infraestructura en América Latina han fracasado en la prevención de conflictos socioambientales. Al mismo tiempo, cuestionamos las nociones de "espacio", "influencia" y "población afectada" detrás de las prácticas de los EIA. Concluimos que los EIA son una tecnología de gobierno propia de la gobernanza ambiental neoliberal que tiene el potencial de excluir las dinámicas socioespaciales de la población local al tiempo que despolitiza los intereses detrás del proyecto. Con este artículo, contribuimos a la aproximación etnográfica a la gubernamentalidad en el contexto de los proyectos de desarrollo de infraestructura en América Latina, y a la comprensión del papel del conocimiento experto y las tecnologías de gobierno en la hidropolítica neoliberal.

Palabras clave: Estudios de Impacto Ambiental (EIA), represas, hidropolítica, tecnologías de gobierno, conflicto social

\section{Introduction}

In Latin America, the last three decades have seen a mushrooming of mining, oil, hydropower and agroindustry projects in areas inhabited by peasant and Indigenous communities. These projects have been associated with neoliberal reforms intended to favor private and international investment, to incorporate new resources in global markets, to activate national economies through tax revenues, and to gain state control over territories, resources, and populations. In this context, water has been increasingly privatized, commoditized, and made available to industrial development, with the State keeping a mild regulatory responsibility but playing a central role in the processes of water appropriation by private groups (Ávila-García 2016).

It is not surprising that in the last decades we have witnessed an increase in the construction of large dams, often destined for energy production or irrigation systems for agroindustry. While dams have been central in the development of civilizations throughout human history (Wittfogel 1957), they have also been strategies of appropriation of water in order to generate revenues for local and regional elites and to become axes of state or private control (see Bakker 2012, 2013). Scholars in political ecology and numerous environmental organizations have documented the negative environmental impacts, the social traumas, and the strong growing opposition to dam projects (see Burrier 2016; Budds 2004; Ribeiro 1994; WCD 2000). As Romero and Sasso (2014: 55) have suggested, the mushrooming of dam projects is an expression of the socio-environmental relations of global capitalism and of structural inequalities of race, class, politics, and spatialities, that generate even more inequality and social exclusion. The dams built today in neoliberal Latin America thus give 
continuity to the history of dispossession and socio-spatial inequality that goes back to colonial times, in which Indigenous and rural groups have been the object of systematic dispossession and acculturation, or even extermination (Alimonda 2011).

Environmental impact assessments - EIAs - are documents prepared before every dam project and involve technical instruments such as the definition of "influence areas" in order to prevent and manage the negative impacts associated with a dam's construction and functioning. EIAs are prepared by project promoters and sent to the competent environmental authority, which is in charge of project review and approval. If the environmental authority considers the EIA to be satisfactory it will give the project a license to begin construction. The growing number of socioenvironmental conflicts associated with dam projects calls for social science to carefully evaluate how infrastructure projects are legitimized, and to what extent they represent the common good. In this article we try to understand the way that different technical instruments work at the micro-level; specifically, whether or not they succeed in their alleged purpose to prevent or to manage such conflicts.

EIAs were adopted in the United States with the passage of the National Environmental Policy Act of 1969 (NEPA) (Halford 1979). From there, they spread to developing countries and were included in national regulations, becoming mandatory in infrastructure projects financed by multilateral organizations such as the World Bank. In Colombia, the EIA requirement became mandatory with the promulgation of Law 99 in 1993 and the various decrees that regulated it, the last of which passed in 2010. Since their establishment as the mainstream procedure to prevent, mitigate, compensate, and repair negative impacts of infrastructure projects, EIAs have been subject to adjustments to make them an effective governance instrument. For example, authors have advocated for the inclusion of sociocultural indicators (Angel, Carmona and Sanchez 2003), analysis with sensitivity toward the social dimension (Cernea 1994), and community-controlled impact assessment, combined with negotiation of binding agreements (O'Faircheallaigh 2017). Also, specialized journals address issues related to them, such as the Environmental Impact Assessment Review. The failure to bridge the distance between aims and practice in many EIAs leads to the question of how they work at the micro-level. How do EIAs contribute to the reproduction of dynamics in which mainly poor communities in rural areas are experiencing the disruptive impacts of projects with minimum or nonexistent benefit for them, fostering social conflict and upheaval? (Martinez-Alier 1995).

In our case study of the Rancheria River project in Colombia we describe how the EIA appears to be an instrument for managing the risks that people and the environment pose to projects, and not the other way around. In other words, EIAs seem to act more as a legitimizing device for projects than as a comprehensive and participative plan to prevent or repair their negative impacts. We identify EIAs as a 'government technology' of neoliberal environmental governance: "a complex of mundane programmes, calculations, techniques, apparatuses, documents, and procedures through which authorities seek to embody and give effect to governmental ambitions" (Rose and Miller 1992: 175). This concept is useful since it accounts for the process of making an EIA that brings together different techniques of analysis and data collection: research procedures, participation and socialization; calculations and algorithms to establish the intensity an extension of the impacts; and a set of devices that privilege expert knowledge that gives the process an aura of objectivity. Nonetheless, we counter the dominant treatment of the EIA as a technical, neutral mechanism for identifying and managing negative impacts. We define it as a deeply political structuring element of neoliberal frameworks of governance that enact particular interests, that often serve the expansion of capital to new areas, and that creates individualistic relationships among local populations.

We pay special attention to one of the techniques that characterize EIAs: the definition of the areas of influence, or the geographical delimitation of the scope of the impacts and management plan. How one defines the areas of influence (and furthermore, how one defines "influence") is fundamental for development projects, because it defines a politics of recognition about who is entitled to compensation from negative impacts, who benefits from the project operation and under which logics and procedures the compensations are to be established. As we show in this article, some communities struggled to be included on the project's "map" of influence either to access the rights and opportunities they imagine it implied, or to demand the recognition of certain impacts that were not adequately assessed. Other communities included in the areas of influence receive a uniform treatment, and therefore some did not receive adequate compensation for the changing intensity of 
the negative impacts in different project phases. The pattern we observed was consistent with the outcomes of dam projects all over Latin America, where small rural or Indigenous communities suffer disproportionate negative impacts. In the Ranchería project, the communities affected by the dam (Caracolí, Chorreras, and Indigenous groups) shared a feeling of disempowerment and had to develop strategies to relate to project agents and the State while the EIA proved insufficient to encompass their demands for recognition.

The article presents an ethnographic account of the Rancheria River Dam project in Colombia, showing how the areas of influence in the EIA serve the interests of the project promoters: local landowner elites interested in agroindustry, coal multinationals, and different levels of State government - municipalities included. The EIA's definition of the areas of influence was a key to generating regional support and obtaining at the regional level the licenses to proceed with the project. At the local level, however, areas of influence and management plans fueled conflicts between the project and rural and ethnic communities, and within communities for adequate compensation or even recognition as affected parties.

Based on the case of the Ranchería dam and inspired by literature in the political ecology of water in Latin America, we suggest that the EIA as a government technology has the potential to reproduce current structures of power and inequality that characterize neoliberal water management and economic policies, and that generate conflict around projects. This happens because the EIA's technical definitions of socioenvironmental impacts, people affected, and geographical space often clash with local worldviews and sociospatial dynamics, turning the instrument into an arena of political struggle.

In what follows, we first present the case and the methods used to approach the problem. Later we present the theoretical framework that allows us to interpret the ethnographical data. In the second part of the article, we present the story of the Ranchería dam project, and how during the EIA process external agents characterized the people and the effects they were supposed to endure, defined the areas of influence, and designed management plans. We trace three stages of the project and the impacts and conflicts that emerged in each one of them: first, the socialization, surveys and consultation processes; second, the construction and its impact management plan; and third, the filling and operation of the dam. We reflect on how the project transformed sociospatial relations and how people faced changes or demanded recognition. Finally, we draw some conclusions about how EIAs operate as technology of government.

\section{Case study and methodology}

The "El Cercado" multipurpose dam is in La Guajira Province in northern Colombia, bordering Venezuela and surrounded by the Atlantic Ocean (Figure 1). The dam is in the mountain range called the Sierra Nevada de Santa Marta on the Ranchería River, which is the primary water source for agriculture nearby and for the population of at least nine municipalities. La Guajira is inhabited by a diverse population that includes Indigenous groups, Afro-descendants, peasants, and rural and urban populations, each of them with a very different relationship with the Ranchería River and with the dam project. Water scarcity in the semi-desert lowlands of the region (that unevenly affects the different social groups), was the justification for the dam, solving land management and social problems.

Regional large landowners envisioned the project in the 1950s, specifically intending to build an irrigation district for agriculture. Over the years, studies were conducted, and the project received more or less attention depending on the government in office. In the late 1990s, after strong pressure from regional elites, the government of President Andres Pastrana (1998-2002) assigned a budget for designs and surveys, but the project never started. The first government of Alvaro Uribe (2002-2006), known for its focus on agroindustry as a development model, gave the Ranchería project its support and declared it a project of "public interest" (CONPES 2005).

To be of "public interest" implied that the State financed 100\% of the EIA and the first phase of the project. The State also assumed the supervision and administration of the project through the regional office of the public agency for rural development -INCODER (Instituto de Desarrollo Rural) - with close participation of the representatives of regional irrigation user associations in the Rancheria river basin (Asosanjuan and Asoranchería), encompassing about a thousand large, medium and small landowners. 


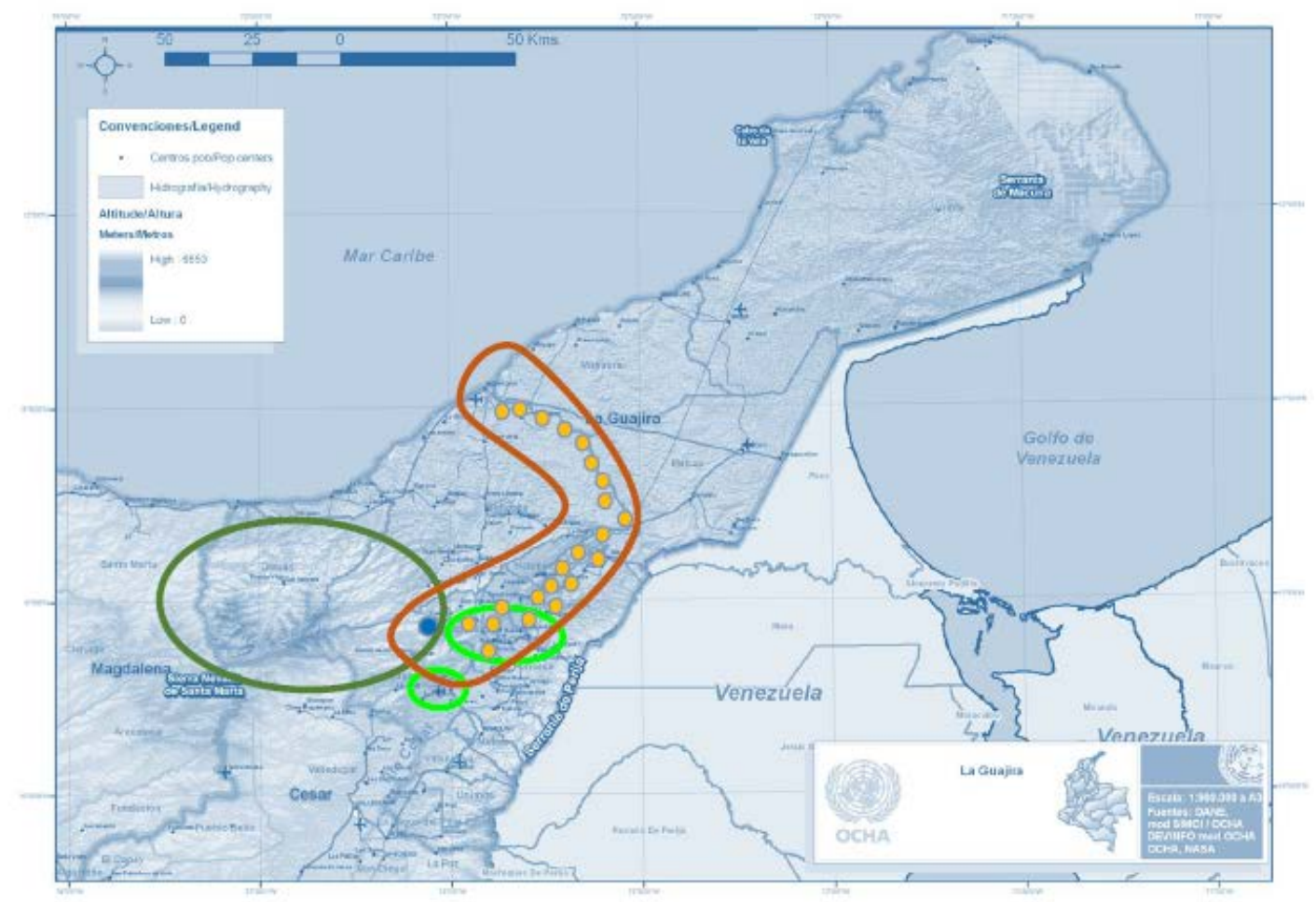

Figure 1: The approximate location of 1) the dam (dark blue); 2) the Sierra Nevada de Santa Marta (dark green); 3) the two irrigation districts planned (light green); 4) the Ranchería river basin (orange); and 5) the location of several Wayuu communities along the river (yellow).

The Ranchería river dam project was designed in four phases to advance its multipurpose objective. The first phase was to build the dam, install the main pipelines of the two irrigation districts, and design an "Agricultural Plan" that promised to turn an area of agricultural holdings for subsistence and local trade into an agroindustry district for exports. This phase is the only that has been completed, as described below. A second phase would consist of installing the irrigation connections to each plot of land and the implementation of the Agricultural Plan. A third phase would connect nine municipal aqueducts. Finally, a fourth phase would install a small hydroelectric plant with the capacity to generate seven megawatts of energy to serve the nearby population of the project area, approximately 3,000 homes.

The Rancheria River project resembles other dams with extensive negative impacts on community life and the environment, such as Urra I, el Quimbo I and Hidrosogamoso in Colombia (Duarte-Abadía, Boelens and Roa-Avendaño 2015), HidroAysén in Chile and El Zapotillo in Mexico (Romero and Sasso 2014) among many others (see the WCD 2000 report). In many of these projects the EIAs are the object of dispute, and sometimes communities are able to introduce modifications to the original designs and the delimitation of the area of influence, as was the case with the Sierra Nevada Indigenous community in our case study. Nonetheless, during its construction the conflicts around the Ranchería dam endured on a private and local scale, without the national and international visibility that many other dam projects have had when NGO, academia and other institutions become actors in the conflicts (Gómez et al. 2014).

During the Ranchería dam building, the local communities in conflict with the project struggled alone, and the project only caught the attention of few scholars who helped one of the affected ethnic communities bring a legal action against it (Alfonso et al. 2011). Recently, the dam has received renewed consideration because in the region of La Guajira water is at the center of socioenvironmental debates, controversies and conflicts, as in many extractivism contexts in Latin America (Bottaro, Latta, and Sola 2014). Recently, the Ranchería River dam has been signaled by activists and community leaders located in the lower sections of the 
river as a part of the systematic appropriation of the river by landowners and the coal mining industry, something that they directly relate to food insecurity and the deaths from malnutrition of thousands of Indigenous children (Guillén 2015).

We take the case of the Ranchería dam as representative of the neoliberal support for agroindustry and water privatization justified through a discourse of public and general wellbeing. The case sheds light on existing social divisions and the privilege of a capitalist view of the economy and sociospatial relations. Although this article does not focus on what has happened to the dam after its construction, it is important to signal that the export-oriented agroindustry that elite landowners envisioned and that many small and medium landowners in the user's associations supported in the first stages has not been developed. Aside from the lack of state financing, the small and medium landowners have been unwilling to alter crop types and to make the necessary investments to change the irrigation systems from canals to sprinkler systems. This early support by the smallholders shows how government technologies attempting to extend market economies can capture the desires and imaginations of people. However, at the time of implementation, these same people faced the less attractive realities of what participating in such endeavors actually means to their ways of life and their relation to land and environment.

The article focuses on the construction of the dam, the delimitation of areas of influence and the relation between different communities and the project agents. The results presented here are part of a larger anthropological research project that aimed to evaluate whether Prior Consultation (as formulated and regulated by ILO Convention 169 and Law 21 in Colombia) served to prevent conflicts in three projects in Colombia. We conducted fieldwork in La Guajira over three non-consecutive months in 2012. Our methodology involved an ethnographic documentation of the experiences and thoughts of several communities inside and outside of areas of influence (as define by the project). Social mapping and territorial tours were done with inhabitants of Caracolí and Wayuu Indigenous communities to collectively produce knowledge about their territories (Montoya, García and Ospina 2014) and, specifically, about their socio-spatial experiences and visions. We conducted in-depth and semi-structured interviews with local leaders, state officials, and former employees of the dam contractor and made tours in the town of Caracolí. We also critically analyzed documents such as the EIA, correspondence between organizations, and press releases. We sought to understand how people perceived changes and impacts in their territory and life after the dam, as well as how their relationships with the project's agents evolved. We were interested in understanding how people interpreted the technical approach used, and contested it. Also, we wanted to identify the strategies of local people concerning the project. Therefore, the narrated experiences of the communities are a methodological point of entry for understanding how conflicts were shaped and the ways in which the management plan and the inclusion or exclusion of people in the areas of influence played a role in these conflicts.

As the political ecology of water shows, the scale of water management is never neutral but always political (Budds and Hinojosa 2012; Ituarte 2015; Swyngedouw 2015). Consequently, the spatial limits of management are related to the institutional frameworks and power relations controlling them. In Latin America, the increasing number of dam projects are part of neoliberal economic policies associated with extractivism and privatization. Neoliberalism can be seen through its inherent logic of capital accumulation (Harvey 2007). Castree (2008) looks at neoliberalism as a model of governance that naturalizes the market to evaluate and distribute good and services for human needs, while F. Li (2009) contends that neoliberal economic reforms promoted knowledge practices such as mechanisms of accountability and transparency that would include the EIA. In practice, we can see how neoliberal economic policies in Latin America have promoted capital intensive mining or agroindustry developments for exports. As has been extensively documented, these policies have reinforced the power of the elites and increased inequality (Budds 2004; Svampa 2015). Neoliberal governance is characterized by promotion of the active involvement of citizens and private actors in the making of policy, the management of public resources such as water, and their positioning as key actors to achieve economic growth and social development. At the same time, however, this apparent democratization of the governmental process contributes to the rooting of individualism and competition in communities with historical, spatial and cultural relationships. Indeed, neoliberalism has also been analyzed as producer of a very special subjectivity (Castree 2010; Rose 1999; Segura 2016).

We recognize with Romero and Sasso (2014) that dam projects are usually materially and discursively linked to the discourse of "development" (Escobar 1995). This discourse implies that dam projects are usually 
linked to a teleology based on western social patterns that promises wellbeing through constant economic growth, and the "domestication" and exploitation of nature. Following this argument, we conceive dam projects as part of (neoliberal) governmentality. The concept of governmentality, as initially proposed by Foucault (2009), refers to the governmental rationality to shape conduct through calculated means for the wellbeing of the population at large. Different from discipline (the exercise of power through the vigilance of the individual), "governmental" power operates through and is distributed in an assemblage of dispositions and techniques that educate desires and creates habits, and therefore detach themselves from specific rulers (T. Li 2007a). This way, governmental power can be exercised by the State, but also by different agents such as private companies, citizens organizations and even by techniques, documents or laws (Rose 1999). One characteristic of the exercise of power of government is that it will always be formulated as an attempt to "improve" the life of the population privileging expert knowledge of science and technology as the best way to achieve it. This focus on technical procedures has the effect of depoliticizing intervention, of framing the governmental decisions and the reflexivity over its failures as matters of technical implementation. However, politics is not external to government but constitutive of it; it is never absolute and exists always in relation to resistance (Foucault 2009; T. Li 2007a).

Following these concepts, we see dam projects as the result of, and reproduced through, the practices founded in government instrumental rationality and international legal agreements over environmental management (Romero and Sasso 2014: 57). We argue that the EIA and its procedures fall under these predefined practices, technical standards, and devices that facilitate resource extraction and water management in neoliberal governance (F. Li 2009). Through the delimitation of "areas of influence", EIAs allow the exercise of government as they appear as neutral and technical while sorting, forming and positioning different groups in relation to governmental programs (T. Li 2007a). This theoretical framework allows understanding EIA practices such as the identification of technical solutions to problems perceived by experts (Rose 1999), a process that has been defined as rendering technical the social problems to justify interventions in the name of public interest and wellbeing ( T. Li 2007b). To locate the experts, their financers, to unveil the logic and values of the rendering technical, and to look at the language, numbers, and representations incorporated in EIA is what constitutes an ethnographic look at governmentality (T. Li 2007a).

For our analysis, we depart from the insights in the political ecology of water and dialogue with anthropological literature concerning expertise, technologies of government, and mapping. We build from works that focus on the materialization of projects through techniques, practices, and knowledge. For example, Carmona \& Jaramillo (2015) showed how, during the impact assessment of a small hydropower plant, experts used standardized methodologies and algorithms to make calculations and commensuration to value impacts. F. Li (2009) shows how the process of making EIAs public can take precedence over their content, that the risks identified in them are those that are technically manageable by the solutions it has to offer, and that they circumscribe the spaces for opposition. Puerta Silva (2010) shows how through different strategies such as personal negotiations and corporate social responsibility, a State and a Corporation created a sense of inevitability about a mining project that resulted in distinct ways of Indigenous people's articulations to the project. Maps have also been signaled as devices for the exercise of power to appropriate a territory. As Pickles (2004) synthesizes, maps are mechanisms of control that define exclusion and inclusion, generate new forms of territoriality, and alter places. Furthermore, Peluso (1995) argues that they also activate identity politics and people's claims to be recognized within a territory.

This literature gave us insights about the effects and procedures of State and private companies to insert projects in territories. However, as the EIA and the definition of the areas of influence of the project are effective government technologies for framing the project according to particular private interests, the case we observed was full of tensions and conflict between affected communities and the project. This leads us to the question of how the EIA techniques of defining areas of influence were contributing to trigger them. Therefore, we looked for answers by questioning the notion of space and social impacts as enacted by EIAs. In global capitalism space in seen as a container where nature offers resources for economic progress. As mentioned before, the neoliberalization of water implies that water is primarily seen as something that can be incorporated into markets or technically managed to efficiently allocate it to industries that produce growth. The social and environmental impacts of a development intervention also appear as something technically manageable, as they are considered to be the predictable result of an action and to be confined to a certain "area of influence." This 
relation to capital accumulation (Harvey 2007) made it difficult for local people to intervene and appropriate not only the standardized technological apparatus but also the idea of development that comes with the projects.

A place-based perspective (Massey 1993) that builds on a long tradition of geographical thinking in which territories are socio-natural productions helped us understand better what an external intervention, such as the building of a dam, imply for neighboring communities (Lefebvre 1991). As Massey suggests, space is best understood as "articulated moments in networks of social relations and understandings" (Massey 1993: 67), instead of bounded areas, which is how the "area of influence" is seen. This suggests that place is a sociohistorical configuration constructed over time through relationships between people and space (the natural environment being a dimension of space). From this perspective, the political ecology of water has explored the mutual relations between territory, water and people (Linton and Budds 2014). Local territories are coproduced in relation to hydro-social dynamics, shaped by physical properties, norms, technologies, institutions, practices, discourses, and meanings that produce and are produced by relations of power (Budds and Hinojosa 2012). Therefore, when the State built the Ranchería Dam, the hydro-social cycle of water appropriated by external agents, and the hydro-social territory was reconfigured and declared an area for intervention. The project brought changes and created a sense of crisis around the Ranchería River that we could see in different manifestations of conflict. The EIA that was produced was not able to capture sociospatial dynamics and to manage the complexity of impacts Instead it predefined and standardized the relation between project agents and people which resulted in the failure of the instrument to prevent social conflict. This technical process actually triggered a variety of conflicts.

We add a perspective to the political ecology of water and development in neoliberal Latin America that focuses on the local functioning of expert knowledge devices (Banerjee 2013; T. Li 2007b; Rose and Miller 1992). With an ethnographic perspective on EIAs as a technology of government, we describe how they reproduce sociohistorical power relations, trigger social conflict, and disempower local communities while favoring the expansion of the market and capitalist logics and values. In this way, we also contribute with ethnographic research to the anthropological call to study governmentality (T. Li 2007a). We argue that socioenvironmental conflicts are inherent to the process of building neoliberal governmentality; a process of continuous disempowerment and dispossession of local populations in which they resist in various ways, but end up contributing to the process in a dramatic strategy of not being left apart from it. We use ethnography to approach the technical process, showing how people both contest the EIA's definition of "areas of influence" and, facing the inevitability of the project, try at the same time, to be included in the "area." Conflicts were only the visible manifestations of the functioning of a management technique that was presented as neutral but that, as local people argue, was arbitrary and unresponsive to local dynamics. At the end it is a government technique because it is able to control the visible resistance of conflict, gain compliance from the local people, and finally, redefine places.

\section{The EIA and the definition of areas of influence in the Ranchería River dam project}

The Ranchería dam (Figure 2) was one of the spearheads of Alvaro Uribe's government (2002-2010) in La Guajira and responded to the interest of the regional government and local landowners who supported it. For decades, the armed conflict in the country affected communities near the area of the Ranchería dam, and during studies the project appeared as the way in which the State would make its presence felt in the Sierra Nevada de Santa Marta, a region controlled for decades by the FARC and paramilitary groups.

To implement the project, the government hired a private contractor (Unión Temporal Guajira - UTG) to do the EIA and the construction works. The project began with the EIA expert technicians of the UTG collecting primary and secondary information about the theoretical "area of influence." In the Ranchería River project EIA "areas of influence" were defined as:

...the analytic space with geographical, environmental, political and social representation in which a project or its associated buildings will be located [...] The environmental management process should be framed in that space, which also constitutes the context in which trends in the environmental dynamics of the region will be identified. (UTG 2004: 7) 


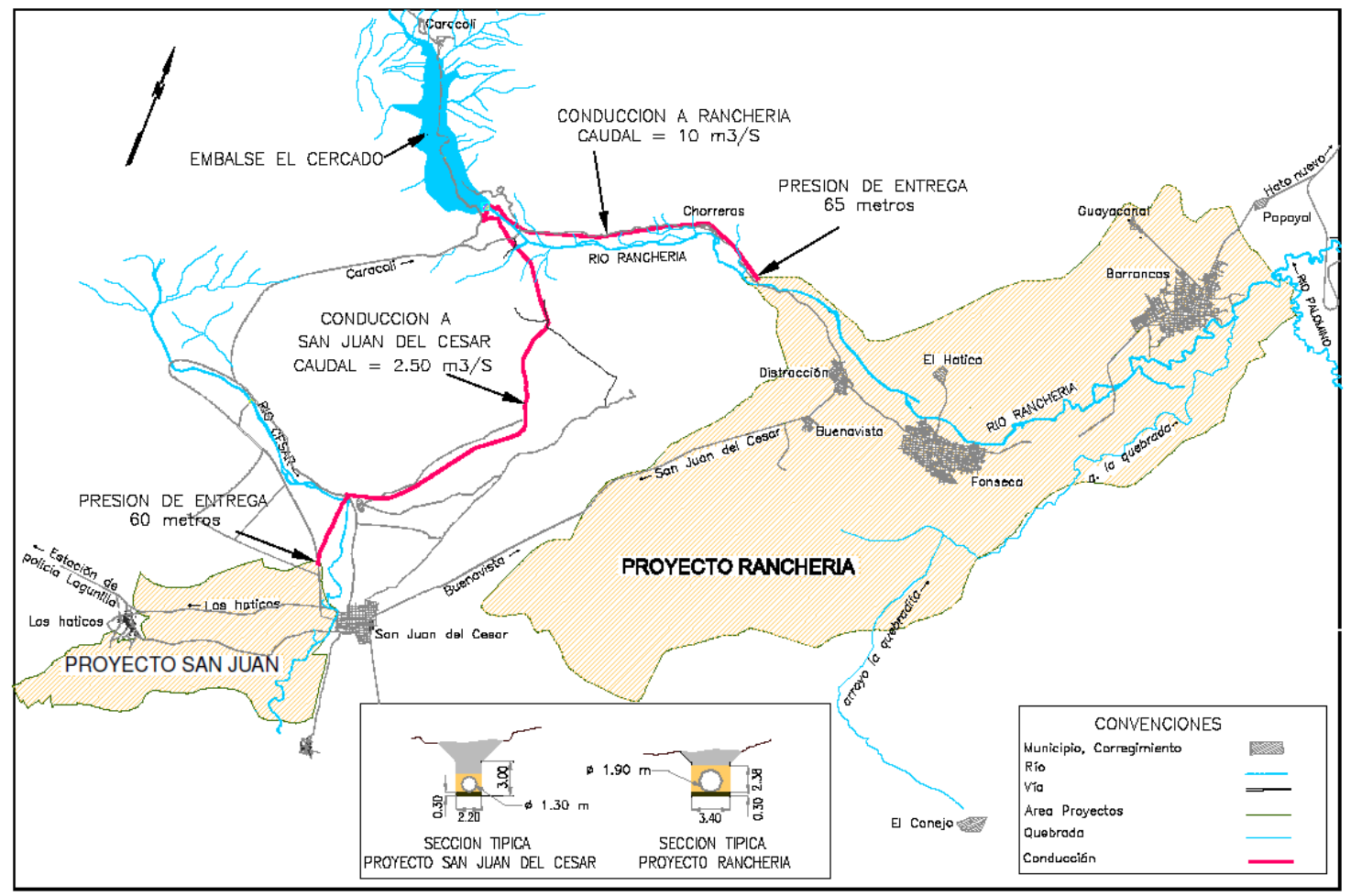

Figure 2: The project, showing the area flooded by dam waters and the two irrigation districts.

In practice, the delimitation of the area of influence involves first the description, or as it is called in EIA jargon, the "characterization of the region": the municipalities and the specific spaces to be immediately affected by the dam and irrigation district infrastructure. In Rancheria this included a physical, biological and demographic description, but also the enumeration of issues considered deficient and in need of rectification. In La Guajira, this included issues such as lack of water supply, low agricultural productivity, inefficient use of water for crops, poverty, high rates of unemployment, and old or inexistent infrastructure, among others. This process can be identified as what anthropologist Tania Li has referred to as "problematization" (T. Li 2007b).

The second task of EIA experts is to anticipate the potential impacts of the project based on the information gathered in the "characterization" to later define programs to address those impacts. According to Serje (2017), the idea of social "impacts" in mainstream environmental management follows a logic of cause and effect, meaning that one specific activity (e.g. flood of productive lands) causes some fairly predictable impacts (e.g. a certain number of people lose their jobs). Here is where the territory becomes subject to technologies of neoliberal governmentality, as problems are rendered technical (see T. Li 2007b; Rose 1999). In other words, problems are represented as susceptible to be solved technically. The "rendering technical" of problems in the EIA occurs when experts frame the compensation offered for adverse impacts as a possible solution not only to avoid, mitigate, compensate or repair adverse impacts but also as the solution to the region's problems. The rendering technical in EIA, therefore, helps to legitimize the project as it links it to the discourse of development and the "improvement" of peoples' lives (Escobar 1995). For example, a common compensation measure is to guarantee a fixed number of jobs for nearby communities, something that an EIA would frame as a solution to a local problem such as "high rates of unemployment." This way, the EIA helps to spread a western perspective of adverse impacts (as compensable) or the benefits as economic growth and increased productivity (the ideals of development). The problem is that, at this stage, the EIA does not consider the dynamic and rhizomatic logics and practices of human social relations, or the different ideals and imaginaries of what development means. As we will see later, far from a relation of cause and effect, the social impacts of projects 
are total 'social facts' to which people assign meaning, representations, and to which they respond in unforeseen ways (Serje 2017).

EIA technicians register and assemble all the technical solutions to identified impacts in a file called the "environmental management plan." The EIA is composed of this document, along with the details of infrastructure works, characterization of the areas of influence, maps, the register of the socialization process with local communities (photos and signatures obtained at meetings) and a cost-benefit analysis. With the EIA assemblage, the project can obtain approval and be licensed by the competent environmental authority. In the case of the Ranchería River project, since the dam had less than 200 million cubic meters, the Corpoguajira (regional level licensing agency) could approve it. As interviews revealed in our fieldwork, the leaders of the users associations (elite landowners) in close collaboration with the regional office of the Incoder (state agency in charge of financing the project) pushed for the dam to be designed with a capacity of 198 million cubic meters. This strategic move was intended in their view to maintain the project licensing at the regional rather than national level, where the regional elite's interests are better represented.

In the Ranchería River Project's EIA, other technical specifications for areas of influence included: the territorial dimension (physical-biotic, political-administrative, and socioeconomic), the kind of influence (either direct or indirect), and the coverage of influence (regional, local, and immediate) (UTG 2004: 7). Following this categorization, EIA experts mostly limited the environmental management plan to local and immediate areas of construction (Chorreras, Caracolí, Zambrano, and Corral de Piedra), as well as lands in nearby irrigation districts that belonged to users associations and Wayuu settlements.

At the same time, other spatial and temporal scales were used to inform the positive impacts of the project. The EIA presented positive impacts that were only possible once the four phases of the project were finished and fully operational, even though the contract with UTG only included the first phase. Project promoters mainly preached the regional benefits of the project, eliciting influence at a regional level. Project promoters and the UTG programmed meetings in the central municipalities (Distracción, Fonseca, and Barrancas), used radio and local newspapers, handed out flyers and announced their plans at sponsored festivals. In these public displays, they provided the same information to those affected by the construction (the local area of influence) and regionally (the indirect area of influence). In the specific meetings with the communities affected by the project (Caracolí, Chorreras, Zambrano, Corral de Piedra, and six Wayuu settlements), the focus of the information was on compensation measures such as social programs, recreation infrastructure, and jobs, which people perceived as positive.

Another example of the IEA framing of impacts concerns the information regarding the number of beneficiaries. According to the EIA, the project would benefit 354,903 people, a direct evocation of the influence on the regional population. However, the real number of beneficiaries for the first and second phase of the project only included 1,029 landowners and their families. Among these, the real beneficiaries would be those who had enough money to invest in modern irrigation technologies. Even then, these families depended on the execution of the second phase of the project that involved the connection of their plots to the main irrigation pipelines (and this is yet to be funded).

The estimated number of new jobs was 10,000, but again, this was only a calculation based on maximum potential, assuming every single hectare of land was equipped with irrigation technology. The same happened with the water supply estimates. Project promoters spoke of supply for nine municipalities (where the number "354,903 people" in the EIA would make sense), but water supply for human consumption was only considered for urban areas. While not denying the importance of urban water supply, it is in rural settlements where there are the most urgent water problems. Hence, the dam did not solve La Guajira's water issues despite claims to the contrary in the press.

Indeed, the selective socialization of the EIA was quite positive for the project's image, since for a long time the project was spoken of as a promise of water for everybody, progress, development, and future wellbeing. A local newspaper described the dam as "the dream of a whole region" (El Pilón 2010). We need to keep in mind that socialization and press releases are part of the EIA itself, so we should not think of this as manipulative project promoters using a neutral technoscientific EIA for their own ends. On the contrary, the EIA's neutral aura is what enables the project to be framed as highly beneficial for development depending on which area of influence is elicited. However, being described as part of an area of direct influence does matter 
for local communities. This is especially true for ethnic communities because it implies that they are entitled to be consulted, to identify the impacts according to their own criteria and to participate in the design of the management plan. The exclusion of several ethnic communities from "areas of influence" in the Rancheria EIA exemplifies this point. As we will see in the next section, it was the first issue to trigger conflict, specifically with the ethnic communities in the Sierra Nevada de Santa Marta.

We have shown how the "neutral" numbers of the EIA allowed the project to gain support from the public at regional and national levels. To achieve this, EIA experts elicited the meaning of "influence" and the area of influence (regional or local) in different ways and at different times. Now, we will describe the experience of the different communities included or excluded from areas of influence.

\section{4. "They do not understand what the river is": prior consultation and Indigenous communities in the Ranchería River project}

Colombia is a signatory to ILO Convention 169, which establishes the right of ethnic minorities to prior consultation on development projects. Before any project begins, applicants for an environmental license must submit a request for information to the Ministry of the Interior about which ethnic minorities in areas of influence need to be consulted. In theory, these groups should help to identify the impacts of projects, but this only happens when prior consultation is done consciously. However, what often occurs is that the Ministry of the Interior points to the groups to be consulted based on the theoretical area identified previously by EIA experts and project designers. Once established, communities outside this original delimitation need to fight their way inside.

In La Guajira the main ethnic group is the Wayuu people who account for almost $48 \%$ of the inhabitants. Most of the Wayuu people live in the Ranchería river basin, which takes its name from this group's housing model based on 'Rancherías' (settlements comprising five or six houses of matrilineal kinship units). Other Indigenous groups live in the Sierra Nevada de Santa Marta, a mountain range administratively divided by three departmental units including La Guajira, seventeen municipalities (the dam is in San Juan del Cesar), three Indigenous reserves, and two national parks. La Sierra Nevada is the territory of four Indigenous groups (Wiwa, Arhuaco, Kankuamo, and Kogui). We will refer to both cases, the Wayuu and the Sierra Nevada Indigenous people, because of the unique experience of each one with the EIA, and the conflicts that have emerged in their relationship with the project.

\section{The Wayuu}

At first, the Ministry of the Interior ordered the EIA consultant to have a consultation process with six Wayuu settlements chosen from over 24 Wayuu Indigenous reserves and a much larger number of settlements located downstream from the dam in the Rancheria River basin (Corpoguajira 2011). The reason for this was the location of the six settlements in the same administrative units as the irrigation districts, and because they could be affected by the installation of irrigation pipelines nearby. These criteria delimited the local area of influence.

As for implementation, even the six communities consulted only received information in a single meeting. The meeting briefings held in the regional environmental authority's archive show a common pattern for all the meetings. First, engineers presented the project highlighting the benefits of the dam for La Guajira's economy. Second, the Indigenous people took the chance to ask the state entities present for solutions to their problems such as water supply for crops or human consumption, housing or employment. To these demands, the representatives of state institutions committed to transmitting the requests but stated that they were not related to the project. Finally, meeting briefings finished with the statement that the community had agreed to the project and highlighted it as an important opportunity for the region to which a list of signatures followed.

After the one consultation in each community, the Wayuu did not hear from the project and only received information from public media. Now that the dam has been built they have experienced major changes in the behavior of the river. As local leaders described to us during interviews, since the dam has been operating the water level changes depending on the opening of the floodgates without warning; and local weather predictions and plans for cultivation based on water levels are no longer useful. The changes in water patterns made the 
dam a symbol of water dispossession in La Guajira, linking it to wider controversies about extractivism and Indigenous rights (see Arboleda et al. 2015; Indepaz 2013).

The inclusion of the six Wayuu settlements did not follow a socio-spatial relational approach to defining areas of influence. If EIA experts had truly considered the vital relationship of the Wayuu with the river and their hydro-social territory, every community from the source to the river's mouth should have, at least, been informed of possible changes - if not consulted. Following a simplistic criterion used to establish limits, EIA experts and the Ministry of Interior excluded most of the Wayuu communities from the right to receive information and prior consultation over the forecast significant change in river dynamics. The importance of including the whole river basin in the EIA process has already been pointed out by the World Commission on Dams (2000). Also, basin management is a widely popular concept in Colombia, and there are specific plans for the most important basins in the country. For the Ranchería basin there was no systematic plan before 2011, yet one can argue that the decision to limit the area of influence to the portion of the river where the dam was to be built was enabled by one of the dimensions of the technical definition of areas of influence in the EIA: physical proximity to the works site.

Consulting a large number of Indigenous communities in the river basin and its banks would have been a much larger task that would have increased the project costs (resulting in an unviable cost-benefit analysis) and extended the implementation timetable. Also, as we heard from project promoters in our fieldwork interviews, to include more Indigenous people in this consultation could have brought more political interest and attention to the project, which was undesirable. Thus, the fact that the direct area of influence included only communities inhabiting the areas where they were going to install the infrastructure, legitimized convenient exclusions. The EIA presented this decision as an apolitical matter.

\section{Sierra Nevada de Santa Marta}

The major conflict regarding prior consultation occurred with the ethnic groups living in the Sierra Nevada de Santa Marta. The EIA mentions the Sierra Nevada as a strategic environment for ensuring the future sustainability of the dam. This vision, in some way, reproduces the idea of "ecological natives", well suited for the upstream protection of the river environment (Ulloa 2004) that other actors will use productively downstream for profit. Nonetheless, they were not even considered in the first stages of the EIA, based on the argument that there are no Indigenous reservations within the 657 hectares of the reservoir.

The Sierra Nevada is the ancestral territory of Wiwa, Kogui, Kankuamo and Arhuaco people, all members of the "Territorial Council of Authorities" (Consejo Territorial de Cabildos). The territorial council is a decision-making body with representatives from the four ethnic groups. The Colombian State recognizes the sovereignty of the Territorial Council over the Sierra Nevada territory, which is further bordered by a series of ritual places comprising the "Black Line" (la Línea Negra). For the four groups, the Sierra Nevada is the center of the world upon which the cosmic balance depends (e.g Uribe 1992). Therefore, the Territorial Council of Authorities must approve significant decisions concerning the entire territory, even those outside the borders of the Indigenous reservations.

During the Ranchería River project EIA, the Territorial Council of Authorities sent several letters to environmental authorities demanding prior consultation based on criteria of influence that had not been recognized by the EIA process. Only after a University review of the EIA was made as part of the requirements for its approval, did project promoters follow the University advice to consult the Wiwas. But only one single meeting of prior consultation was held with a Wiwa community living close to the dam. One might say that this was a partial success, since Indigenous people fought their way into the "direct" area of influence. However, the inclusion was only partial. At the meeting, the Wiwa leaders living close to the dam demanded that the Territorial Council of Authorities be included in the planning, and a specific timeline and length for the consultation process be established. The project promoters did not accept these requests. Wielding the registration list and signatures of those who attended the meeting, they argued that they had accomplished the consultation requirement. The regional environmental authority granted the license for the dam project, and the construction began. Unhappy with the consultation meeting and with the dam project, the Wiwa organized marches and protests in front of the construction site. 
In a struggle to be recognized as affected peoples, the Territorial Council of Authorities continued sending letters, but the environmental authorities barely heard them. In a direct attempt to signal that their opposition was absurd, one of the leading national newspapers reported the headline: "Wiwa Indigenous oppose dam that will take water to the desert of La Guajira" (El Tiempo 2007). Only the definitive version of the EIA recognized the existence of a "cultural" presence in the vast territory of the Sierra Nevada and signaled six points on the "Black Line" as being within the limits of the reservoir, the river and the irrigation districts (UTG 2004: 537-538). The UTG also allowed the performance of some ritual events in the six points of the Black Line, and at archeological sites. This was a strategy to calm protestors. Although the definition of the area of influence considers cultural -and not only physical- influences, EIA experts only allowed for rituals after conflict had emerged. Also, they interpreted Wiwa opposition to come from pure economic interest, as one representative of the project board made clear when he argued during an interview that "all they wanted was money." This way, project promoters delegitimized any attempt by the Territorial Council of Authorities to establish negotiations.

What the project promoters did not recognize was that for the Indigenous people in the Sierra Nevada, the Ranchería River is much more than a resource or a place of recreation. For them, the river is a ritual space; it is indivisible and part of a flux that cannot be interrupted by the wall of a dam, at least not without performing rituals that reestablish the equilibrium and help them to make sense of it. Also, the proponents ignored the residents' affective and material bonds to the land and to other human and non-human beings that comprise their territory in the Sierra Nevada. Therefore, the Indigenous people of the Sierra felt entitled to be consulted and to negotiate in their best interest, not only to take care of their territory but to reinforce the recognition of their sovereignty over it. "They do not understand what the river is", a Wiwa told us in speaking about the process (see Czernietzki 2008).

With no other solution, the Territorial Council filed a lawsuit for the violation of their right to prior consultation. After years of legal struggle, the Supreme Court of Justice concluded that the proponents had indeed violated the effective protocols for prior consultation. However, because of the "principle of immediacy" which establishes that the plaintiffs must file the lawsuit within a year of the violation of their rights- the lawsuit did not move forward (for an extensive review of the process see Alfonso et al. 2011).

We interpret the struggle of the four Indigenous groups in the Sierra Nevada with the Ranchería project as a failed attempt to participate in the apparatus of the state. They were not able to include their own categories and terms of negotiation in the territorial delimitation of areas of influence, nor to shift the meaning of "influence." The situation shows the shortcomings in the EIA conceptualization of space (the 'areas of influence') as a container with delimited borders. But the definition of what counts as "influence" is also problematic. Because of these problems the EIA triggered a conflict and prevented the inclusion of affected populations in the management of project impacts.

\section{The construction phase: the same management plan for dissimilar situations}

So far, we have shown how the Rancheria EIA maintained a hierarchical view of what counts as legitimate knowledge and procedures, by excluding the Indigenous people of in Sierra Nevada. We also showed how it enabled the dam's proponents to depict it as meeting regional needs, and as a legitimate way to solve "water scarcity" in La Guajira. Nonetheless, there were other moments during the dam construction phase when the EIA failed to prevent and even triggered conflict. A principle bone of contention was that the definition of areas of influence led to unfair or insufficient compensation for some affected communities.

In 2006, the regional environmental licensing agency granted a license for the Ranchería River project, and the construction began. The contractor started to implement the management plans for the construction phase in "the immediate area of influence", defined in the EIA as the area to be affected by construction works. The immediate area of influence included "the towns of Chorreras, Caracolí, and [the towns of Zambrano and Corral de Piedra near the San Juan irrigation district] areas close to the site of the proposed dam and central pipelines and future land in the Ranchería irrigation district" (UTG 2004: 7).

We argue that although the four towns all fell within the common category of "immediate area of influence", the proportion of positive and adverse impacts among them varied, as we deduced from empirical data. Numerous factors shape the relations with the project, so each local community experienced negative 
impacts at different moments and with different intensity, revealing a temporal issue that is not adequately accounted for in EIAs. The compensation programs were the same, however, for different negative impacts in different townsites. The category of "the immediate area of influence" functioned as a homogenizing device that failed to consider the specificities of places, resulting in quite similar management plans for very different experiences. In the construction phase, it was Chorreras, Zambrano and Corral de Piedra that experienced negative impacts, while Caracolí did not experience significant issues until the reservoir filled.

The first town affected was Chorreras, a small settlement of rice farmers only ten minutes from the closest urban setting and located downstream from the dam wall, close to the project headquarters and working areas. Chorreras residents were direct witnesses to the adverse effects of construction, and they protested by blocking the arrival of workers several times while complaining of noise, explosions, dust, and the passing of heavy machinery. Their primary demand was for qualified jobs since many people were professionals and the project only offered unskilled labor positions. They also had to address two episodes related to the building of the dam: the closure of the river, which threatened rice crops, and a massive fish mortality episode due to improper cleaning of the deviation tunnel in the dam.

The second and third villages considered "immediate areas of influence" were the small towns of Zambrano and Corral de Piedra, which are mostly inhabited by small landholders and cattle ranchers. The criterion for their inclusion was their proximity to the pipelines. Both towns are located more than an hour and a half away from the dam, and neither is in the Ranchería River basin. In the interviews we held, people said that the burying of the pipelines took a few weeks, and they did not report any significant adverse impacts. They also said they wished for more projects like the dam because it brought steady jobs, social programs, and compensation.

The UTG agreed with the communities on a predefined budget for social programs and compensation. They conducted a selection by votes for the preferred choice among the ideas collected in each locality. That way, the UTG declared that the compensation agreements were the result of a participatory process. In the case of Zambrano, UTG remodeled the church and the communal house. For Corral de Piedra, the construction company improved the rural school and the central park. In Chorreras, it was the cemetery, and in Caracolí, UTG remodeled the central park and repaired the basketball field.

\section{Filling the dam: facing the unexpected}

While Caracolí did not experience significant adverse impacts during the construction of the dam wall, its residents were deeply affected by the final phase of the project. Their case raises the question of how the EIA, and specifically its management plan, failed to incorporate local knowledge in order to anticipate possible negative unexpected impacts. This failure shows how the project promoters maintained a relationship with a small rural community that kept it in a subordinate position.

Caracolí is a small farming village inhabited by peasants and Indigenous Wiwa, located upriver and right at the maximum height of dam waters at the foot of the Sierra Nevada de Santa Marta. This zone was for decades deeply affected by Colombia's armed conflict and limited State presence. Because of the delicate situation, the EIA technicians cited safety problems and instead of generating new data used outdated information and secondary sources to characterize the community.

Paramilitary groups displaced Caracolí people in 2002, four years before the construction works began. At this time, the paramilitary army killed several Indigenous leaders, and the Inter-American Commission on Human Rights declared precautionary measures to protect Indigenous people in 2005 (CIDH 2005). Some interviewees indirectly insinuated that the paramilitary presence opened the doors to the establishment of the project, a dynamic that has been seen in other places in Colombia (see Duncan 2009). Whether or not the paramilitary and the dam project are related, the situation of violence prevented people from protesting and making claims after the negative impacts hit the town.

At first, the construction of the dam represented a sort of revival for Caracolí (Figure 3). The national army arrived in town for the first time in decades, and the project hired some residents as laborers. As in the other towns, early socialization meetings focused on the expected positive outcomes: employment, social 
programs, compensation and in the case of Caracolí, on tourism as an expected consequence of the dam and an opportunity for diversifying sources of income

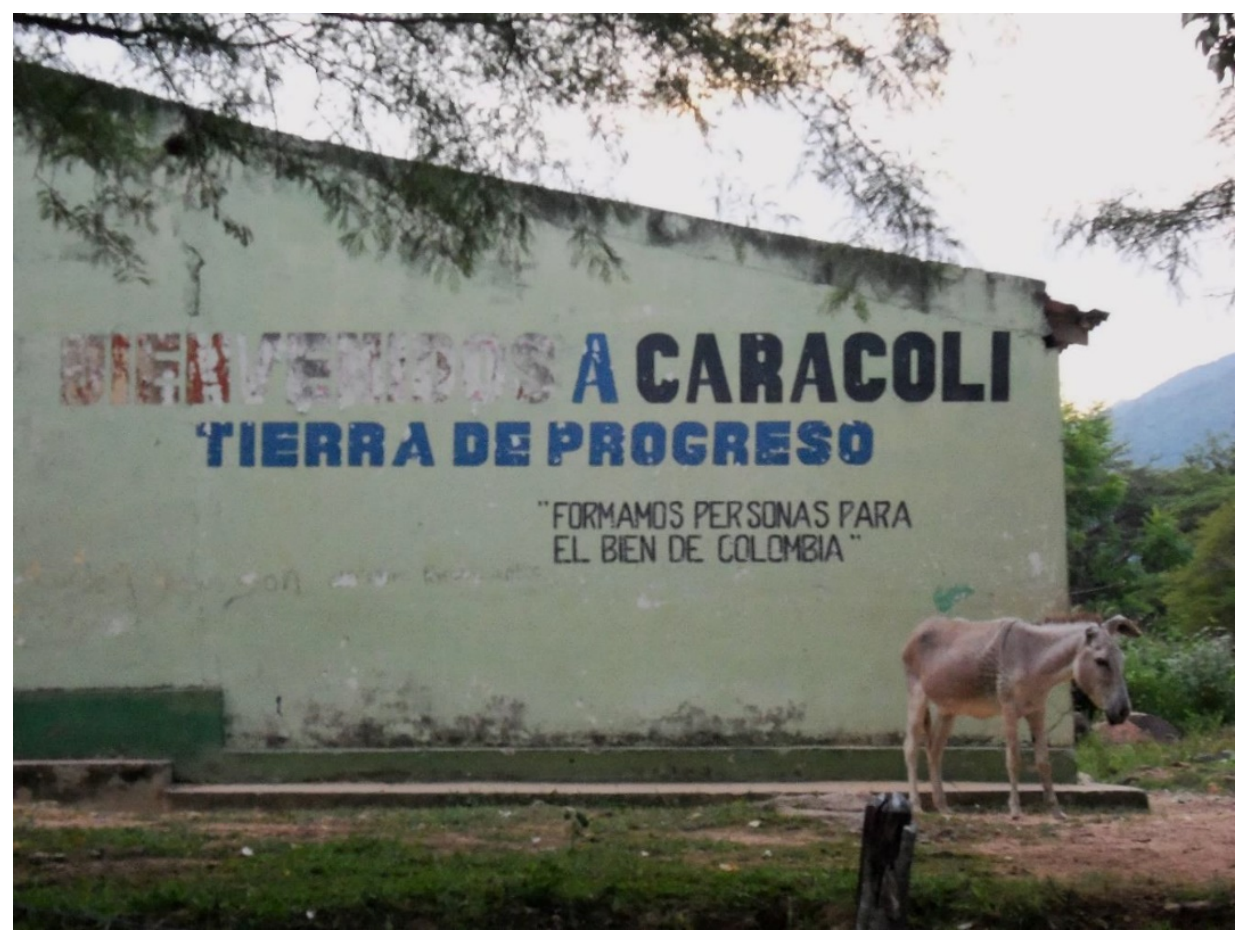

Figure 3: A house in the town in Caracolí. The sign reads: "Welcome to Caracolí. Land of progress. 'We shape people for the good of Colombia'."

However, this optimism came to a definitive end with the inauguration of the dam in 2010. The experts calculated that the dam would fill up in about four years, and people in Caracolí trusted this prediction and continued cultivating the land in the area to be flooded. However, at the end of 2010, the weather phenomenon of "La Niña" caused the river to rise and exceed the 198 million cubic meters of the dam capacity in just four months. Premature filling caused several negative environmental and social impacts. First, many people lost their crops. Second, a micro-hydroelectric power plant that gave the town free, independent and self-sustaining electricity also flooded, even after the constant warnings of people and the environmental authority. An Incoder manager expressed her vision of this problem to us in an interview where she diminished its importance by saying: "people in Caracolí do not really need electricity, they only want it for loud music and to keep the ventilators on." This statement showed us how government officials sometimes think of rural communities as a second category of citizens who do not have the same needs and rights of the urban upper classes to which planners and project promoters belong.

Additionally, the contractor had not finished removing biomass when the river rose, and a massive amount of plant material decomposed, generating terrible odors that were noticeable during our initial visits. The phenomenon seems to have caused a proliferation of mosquitoes, and a dengue epidemic hit 100 people, claiming three lives in Caracolí. People attributed these unfortunate deaths to the dam because dengue had never been a local problem, but after investigation, the health authorities alleged that no link could be technically proven. Some people assured us they had warned the technical staff that the river would increase and that they could not trust its apparent low level. This is one of the situations that shows the subordinate position in which technicians conceive local people and their knowledge, one that is considered subjective and non-scientific.

Other negative impacts experienced in Caracolí include increased transportation time to the municipality and local markets, driving up the cost of selling crops; the isolation of farms from the town center, where the 
school and the health center are; and several landslides on the new road that isolated the whole town for several days on end. Additionally, the promise of tourism as a new economic activity never materialized. Local people were never entirely convinced, and the project did not install tourism infrastructure or capacities. A local leader, while showing his weathered hands that revealed a life of farming, expressed a general disappointment: "These hands know nothing about tourism."

As these events unfolded, the predefined management plan was unable to address the unexpected impacts and peoples' demands for compensation and information. As we mentioned before, Caracolí was treated the same as the other three towns in the area of influence, and therefore the budget, human capacity, and levels of attention were dispersed when negative consequences started to unfold. The EIA, a management tool supposedly aimed at guaranteeing people's rights in case of negative impacts, thus became entirely obsolete. Furthermore, people in Caracolí did not even have copies of the EIA and were never able to use it as a tool to reclaim compensation. Consequently, as in the case of the ethnic groups in the Sierra Nevada, Caracolí's battle for compensation was not mediated by the management plan but had to go through legal channels. The regional ombudsman's office (Procuraduría) intervened and sued Incoder on behalf of the people of Caracolí for the negative impacts they had suffered.

Today, almost nine years after these events, people's visions of their future face a new reality. The dam has become part of the landscape, social life, and collective discussions, as it is now part of the Sierra Nevada waterscape. Local people have begun to adapt to the resulting geographic and landscape changes while they yearn for the land and the river as they were before. They have found other routes to visit relatives and learned how to use canoes and to fish in the dam, even though it is forbidden. Four years after the Procuraduría filed the lawsuit, the town obtained as compensation an electrical interconnection (although it is still not working optimally). The river was, and still is, a recreation site, a source of clean water, and a space for socialization and economic activities, yet the transformations of the landscape changed social relations between people and nature and generated new actors and economic interests.

\section{Discussion: environmental impact assessment as a government technology}

The Ranchería case shows that environmental impact assessments fail to prevent conflict because the implement a politics of recognition driven by a cost-benefit analysis and supposedly technical standards about physical proximity. Conflicts emerge as communities actively resist the fragmentation of hydro-social territories, the private appropriation of water and the difficulties of obtaining adequate compensation. Furthermore, the delimitation of areas of influence triggered conflict even before the project started when groups that considered themselves to be affected contested the State development model of agroindustry and privatization of their lands and rivers, and their exclusion from compensation.

We affirm that even though it is considered "normal" that projects produce some externalities, the rationalities of government results in communities having very little voice, even after legal claims and delays. These often occur too late to avert negative impacts, for their livelihoods, their own future, and the region. Current EIA procedures may seem useful for guiding environmental management, and academics try to make them more comprehensive or participatory. It is not necessarily that EIA fails to recognize the sociospatial configuration of places, but rather that in their interpretation and execution EIAs tend to reduce sociospatial configurations to physical traits. Consequently, the EIAs help governments to consolidate top-down policies that extend the neoliberal model into local territories and deteriorate local subsistence economies and landscapes.

We want to elaborate two reflections. First, for any development or infrastructure project, it is mandatory to assess potential negative impacts. However, as Serje (2017) has argued, the definition, identification, and management of "social impacts" must transcend the tautological conception of cause and effect. The problem is not the change itself, but how people perceive infrastructure effects: whether the impacts of projects meet their expectations or whether they instead feel they are subjected to conditions that take away their capacities and possibilities. In the case analyzed, communities had to resort to legal mechanisms to enforce their rights and to protect their territory, because the EIA went against their interests and aspirations.

In this sense, we argue that areas of influence in EIAs are not conceived as inherently dynamic sociospaces but as predefined rigid lines on a zoning map. The influence of a project is an ongoing borderless 
relationship where the criterion of geographical proximity or administrative coverage is insufficient, and fails to recognize livelihoods and lifeways that are relational and dynamic. Cultural and territorial rights matter. As the case showed, project proponents did not identify sociospatial relations, which is a crucial step in identifying potential adverse impacts, even those impacts that do not seem so important at first sight. Second, planners and local people (whether they have an ethnic identity or not) did not come together to think about possible changes and procedures to face the unexpected, and they did not participate in management on equal terms.

The second and more critical reflection that we can draw from the Ranchería dam project is that EIAs fail in their attempt to prevent or manage impacts (and conflicts) because they work as a governmental technology that helps to consolidate a system of exclusion. In the case of the Ranchería dam, the EIA as a technology of government, promoted the dispossession of land and water from rural and Indigenous communities, whose ways of life were not amenable to privatization and capitalist production.

A specific challenge emerges in La Guajira context. Several projects are currently proposed for this region. The risk that the interests of the governing elites and the global dynamics of extractivism continue driving landscape transformation is very high, as several mining endeavors show. In this context, EIA procedures continue to exclude entire populations from the definition of their future, dispossessing them of their right to autonomy in their territories. It goes without saying that the technique employed by the state maintains them in a subordinated position, not only because they have to seek inclusion in the inevitable economic projects that follow, but also because their situated, historical knowledge and their experiences are disregarded. State responsibilities to maintain quality of life through attention to water quality and quantity, air quality, land use and many more issues, are negotiated as part of the EIA management plans that ignore that compensation is meant to be for losses and negative impacts. Therefore, EIAs and licensing laws, in general, are part of the nexus of power controlling development in general and hydropolitics in particular, in the sense that they serve to disempower and subordinate local populations that have already been excluded from political decision making and wealth distribution.

\section{Conclusions}

In this article, we showed how the Ranchería project was intended to transform the Guajira region of Colombia into an agroindustry district, and to do so it required the State appropriation and control of water resources for private purposes. In this way, the EIA fostered the appropriation of water by landowner elites and contributed to processes of dispossession of rural and Indigenous communities while the government presented the interventions as aimed at the wellbeing of the entire population. Thus, EIAs in projects for industries such as agro-exports, mining, and hydropower in Latin America help to exercise governmentality aimed at expanding neoliberalism and the transformation of landscapes and local cultures. To show the EIA's operating mechanism, we detailed how technical experts classified territories and predefined compensation for adverse impacts. These practices were limited by their static nature and used very limited spatial criteria of proximity or administrative coverage, both indifferent to attachment to place (or socio-space). However, beyond the strategic omission of hydro-social dynamics to make the project viable, we showed that it is not necessarily that areas of influence in EIA fail to recognize the sociospatial configuration of places, but that they are technically crafted to render them invisible.

While there is no guarantee for fair and adequate management and compensation for adverse impacts for those included in areas of influence, those that are excluded may struggle to be recognized as affected and to enjoy some of the limited benefits of the projects, such as temporary employment and community infrastructure. Therefore, despite its shortcomings the EIA continues to be the framework in which communities demand recognition of impacts, which shows the importance of analyzing this type of governmental technology. While the social conflicts associated with the Rancheria project were not very visible, this cannot be interpreted as the absence of conflict. Rather, the conflict remained confined to a private and local scale, and was managed in an individualistic way. This shows how the relational mechanisms of neoliberal governmentality fracture solidarity and empathy, and consequently, the possibilities of collective actions and social movements. To sum up, our analysis of the areas of influence in the EIA of the Rancheria project not only aimed to identify problems with its implementation, but also to challenge the concept itself by questioning 
the notions of space, influence, social impacts, the apolitical and technical objectivity claim, and the economic model that came with all of this.

Our ethnographic approach to the EIA of the Ranchería River dam allowed us to understand how it functions as a technology. We have contributed to the literature in three ways. First, we have identified the role of this current standardized intervention (the project itself and the EIA) in socio-environmental conflicts and recognized the adverse neoliberal model of water management that is dispossessing local peoples. Second, we have developed the ethnographic approach to governmentality and social conflicts that emerge from the implementation of infrastructure building projects and its government technologies. Third and finally, we have contributed to the discussion in Latin American political ecology with an understanding of the role of expert knowledge and devices in hydropolitics, and the social technologies of government for the general expansion of neoliberalism.

\section{References}

Alfonso, T., L. Grueso, M. Prada and Y. Salinas. 2011. El proyecto sobre el Río Ranchería: La represa de El Cercado. In Derechos enterrados. Comunidades étnicas y campesinas en Colombia, nueve casos de estudio. Bogotá: Ediciones Uniandes.

Alimonda, H. 2011. La colonialidad de la naturaleza. Una aproximación a la ecología política Latinoamericana. In La naturaleza colonizada. Ecología política y minería en América Latina. Buenos Aires: CLACSO y Ediciones CICCUS.

Ángel, E., S.I Carmona and F. Sánchez. 2003. Indicadores socioculturales para la evaluación y seguimiento de la dimensión social en los EIA Y PMA. Medellín: Universidad Nacional de Colombia. summary

Archila, M. (ed). 2015. "Hasta cuando soñemos": extractivismo e interculturalidad en el sur de la Guajira. Bogotá: CINEP/Programa por la Paz.

Ávila-García, P. 2016. Hacia una ecología política del agua en Latinoamérica. Revista de Estudios Sociales 55: 18-31.

Bakker, K. 2012. Water: political, biopolitical, material. Social Studies of Science 42(4): 616-623.

Bakker, K. 2013. Neoliberal versus postneoliberal water: geographies of privatization and resistance. Annals of the Association of American Geographers 103(2): 253-260.

Banerjee, D. 2013. Environmental justice and the state: expert knowledge and local discourses in an environmental justice movement. Environmental Justice 6(5): 183-187.

Bottaro, L., A. Latta and M. Sola. 2014. La politización del agua en los conflictos por la megaminería: discursos y resistencias en Chile y Argentina. European Review of Latin American and Caribbean Studies / Revista Europea de Estudios Latinoamericanos y del Caribe 97: 97-115.

Budds, J. 2004. Power, nature and neoliberalism: the political ecology of water in Chile. Singapore Journal of Tropical Geography 25(3): 322-342.

Budds, J. and L. Hinojosa. 2012. Restructuring and rescaling water governance in mining contexts: the coproduction of waterscapes in Peru. Water Alternatives 5(1): 119-137.

Burrier, G. 2016. The developmental state, civil society, and hydroelectric politics in Brazil. The Journal of Environment and Development 25(3): 332-358.

Carmona, S. and P. Jaramillo. 2015. Números, conmensuración y gobernanza en los estudios de impacto ambiental. Revista Iberoamericana de Ciencia, Tecnología y Sociedad 10(30): 61-79.

Castree, N. 2008. Neoliberalising nature: the logics of deregulation and reregulation. Environment and Planning A: Economy and Space 40(1): 131-152.

Castree, N. 2010. Neoliberalism and the biophysical environment: a synthesis and evaluation of the research. Environment and Society: Advances in Research 1(1): 5-45.

Cernea, M.M. 1994. Using knowledge from social science in development projects. Project Appraisal 9(2): 8394.

Comisión Interamericana de Derechos Humanos (CIDH). 2005. Medidas cautelares 2005 - Colombia. [accessed February 28 2017]. 
Consejo Nacional de Política Económica y Social (CONPES) 2005. Conpes 3362. Importancia estratégica de la construcción de la presa El Cercado y las conducciones principales hacia las áreas de Ranchería y San Juan del Cesar. [accessed December 12 2020].

Corpoguajira. 2011. Plan de ordenamiento de la Cuenca del Río Ranchería. Diagnóstico general. Tomo 2. CORPOGUAJIRA.

Czernietzki, K.J. 2008. El desarrollo nacional versus la cosmovisión indígena: el caso de la represa del Río Ranchería como megaproyecto en la Sierra Nevada de Santa Marta. Masters Thesis. Bogotá: Universidad de Los Andes.

Duarte-Abadía, B., R.A Boelens and T. Roa-Avendaño. 2015. Hydropower, encroachment and the re-patterning of hydrosocial territory: the case of Hidrosogamoso in Colombia. Human Organization 74(3): 243-254.

Duncan, G. 2009. Los señores de la guerra. De paramilitares, mafiosos y autodefensas en Colombia. Bogotá: Ediciones Planeta, Colombiana Fundación Seguridad y Democracia.

El Pilón. 2010. Represa del Río Ranchería: palanca de bienestar agrícola y ambiental de La Guajira. El Pilón. [accessed February 28 2017]. http://elpilon.com.co/represa-del-rio-rancheria-palanca-de-bienestaragricola-y-ambiental-de-la-guajira/

El Tiempo. 2007. Indígenas wiwa se oponen a represa que llevará agua al desierto de La Guajira. El Tiempo. [accessed March 4 2017]. http://www.eltiempo.com/archivo/documento/CMS-3657151

Escobar, A. 1995. Encountering development: the making and unmaking of the third world. Princeton: Princeton University Press.

Foucault, M. 2009[2004]. Security, territory, population: lectures at the Collège de France 1977-1978. New York: Macmillan.

Gómez, A., L. Wagner, B. Torres, F. Martín and F. Rojas. 2014. Resistencias sociales en contra de los megaproyectos hídricos en América Latina. European Review of Latin American and Caribbean Studies / Revista Europea de Estudios Latinoamericanos y del Caribe 97: 75-96.

Guillén, G. 2015. El río que se robaron. Video.

Halford, D.K. 1979. Environmental impact assessment. Ecology 60(5): 1078-1079.

Harvey, D. 2007. A brief history of neoliberalism. Oxford: Oxford University Press.

Indepaz. 2013. El río Ranchería, perdido en el desierto. Bogotá: Indepaz Ediciones.

Ituarte, L.D.M. 2015. Ecología política y escalas en la gestión del agua. Cuencas hidrográficas, estados y poderes territoriales en la Península Ibérica (España y Portugal). Revista Geoamazônia 3(6): 54-82.

Lefebvre, H. 1991[1974]. The production of space. Oxford: Blackwell.

Li, F. 2009. Documenting accountability: environmental impact assessment in a Peruvian mining project. PoLAR: Political and Legal Anthropology Review 32(2): 218-236.

Li, T. 2007a. Governmentality. Anthropologica 49(2): 275-281.

$\mathrm{Li}, \mathrm{T}$. 2007b. The will to improve: governmentality, development, and the practice of politics. Durham: Duke University Press.

Linton, J. and J. Budds. 2014. The hydrosocial cycle: defining and mobilizing a relational-dialectical approach to water. Geoforum 57: 170-180.

Martinez-Alier, J. 1995. Political ecology, distributional conflicts, and economic incommensurability. New Left Review 211: 70.

Massey, D. 1993. Power-geometry and a progressive sense of place. In J. Bird, B. Curtis, T. Putnam and G. Robertson (eds.). Mapping the future: local cultures, global change. London: Routledge. Pp. 59-69.

Montoya, V., A. García and C.A. Ospina. 2014. Andar dibujando y dibujar andando: cartografía social y producción colectiva de conocimientos. Nómadas 40: 191-205.

O'Faircheallaigh, C. 2017. Shaping projects, shaping impacts: community-controlled impact assessments and negotiated agreements. Third World Quarterly 38(5): 1181-1197.

Peluso, N.L. 1995. Whose woods are these? Counter-mapping forest territories in Kalimantan, Indonesia. Antipode 27(4): 383-406. 
Puerta Silva, C. 2010. El proyecto del Cerrejón: un espacio relacional para los indígenas wayuu, la empresa minera y el Estado colombiano. Boletín de Antropología 24(41): 149-179.

Ribeiro, G.L. 1994. Transnational capitalism and hydropolitics in Argentina: the Yacyretá High Dam. Gainesville: University of Florida Press.

Romero, H. and J. Sasso. 2014. Proyectos hídricos y ecología política del desarrollo en Latinoamérica: hacia un marco analítico. European Review of Latin American and Caribbean Studies / Revista Europea de Estudios Latinoamericanos y del Caribe 97: 55-74.

Rose, N. 1999. Powers of freedom: reframing political thought. Cambridge: Cambridge University Press.

Rose, N. and P. Miller. 1992. Political power beyond the state: problematics of government. The British Journal of Sociology 43(2): 173-205.

Segura, J.M. 2016. Empresa, poder e individuo: el neoliberalismo como productor de subjetividad. Civilizar Ciencias Sociales y Humanas 16: 113-126.

Serje, M. 2010. Introducción: desarrollo y conflicto. In M. Serje (ed.), Desarrollo y conflicto: territorios, recursos y paisajes en la historia oculta de los proyectos y políticas. Bogotá: Ediciones Uniandes.

Serje, M. 2017. Social relations: a critical reflection on the notion of social impacts as change. Environmental Impact Assessment Review 65: 139-146.

Svampa, M. 2015. Commodities consensus: neoextractivism and enclosure of the commons in Latin America. South Atlantic Quarterly 114(1): 65-82.

Ulloa, A. 2004. La construcción del nativo ecológico. Bogotá: Instituto Colombiano de Antropología e Historia -ICANH- COLCIENCIAS.

Uribe, C.A. 1992. Geografía humana de Colombia: nordeste indígena. Bogotá: Instituto Colombiano de Cultura Hispánica.

Unión Temporal Guajira (UTG). 2004. Estudio de impacto ambiental y plan de manejo ambiental proyecto Río Ranchería. Distrito de riego Ranchería y suministro a distrito San Juan del Cesar. Contrato No.0140/01 cedido por INAT a Incoder.

World Commission on Dams (WCD). 2000. Dams and development: a new framework for decision-making. The report of the World Commission on Dams. London: Earthscan.

Wittfogel, K.A. 1957. Oriental despotism: a comparative study of total power. New Haven: Yale University Press. 